Energy Division

\title{
REPORT STYLE GUIDE FOR SUBCONTRACTORS OF THE EFFICIENCY AND RENEWABLES RESEARCH SECTION, ENERGY DIVISION, \\ OAK RIDGE NATIONAL LABORATORY
}

\author{
T. A. Stone
}

M. N. Bennett

September 1992

Prepared by

Energy Division Publications Office

Oak Ridge National Laboratory

OAK RIDGE NATIONAL LABORATORY

P.O. Box 2008

Oak Ridge, Tennessee 37831

managed by

MARTIN MARIETTA ENERGY SYSTEMS, INC.

for the

U.S. DEPARTMENT OF ENERGY

under Contract DE-AC05-84OR21400

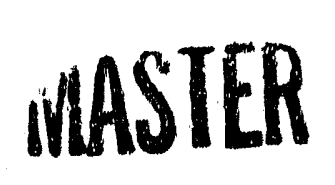


LIST OF EXHIBITS $\ldots \ldots \ldots \ldots \ldots \ldots \ldots \ldots \ldots \ldots \ldots \ldots \ldots \ldots \ldots$ ACKNOWLEDGNENTS $\ldots \ldots \ldots \ldots \ldots \ldots \ldots \ldots \ldots \ldots \ldots \ldots$

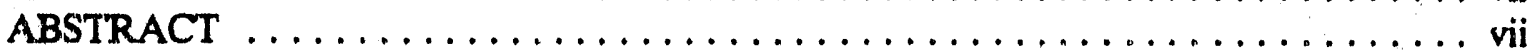

1. INTRODUCTION $\ldots \ldots \ldots \ldots \ldots \ldots \ldots \ldots \ldots \ldots \ldots \ldots \ldots \ldots \ldots$

2. TYPING INSTRUCTIONS $\ldots \ldots \ldots \ldots \ldots \ldots \ldots \ldots \ldots \ldots \ldots \ldots \ldots$

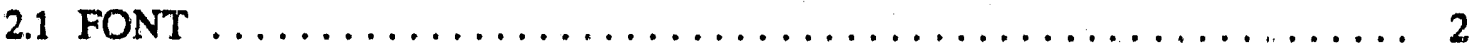

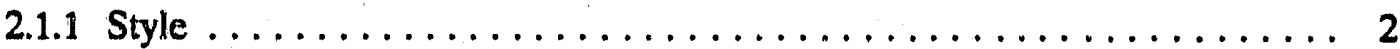

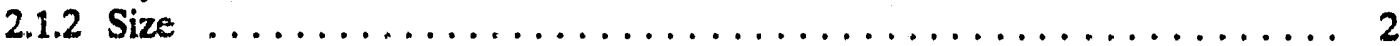

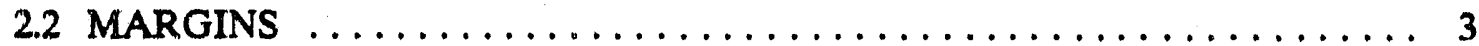

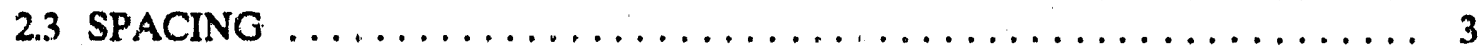

2.3.1 Vertical ............................... 3

2.3.2 I'orizontal $\ldots \ldots \ldots \ldots \ldots \ldots \ldots \ldots \ldots \ldots \ldots \ldots \ldots \ldots \ldots$

3. DOCUMENT FORMAT $\ldots \ldots \ldots \ldots \ldots \ldots \ldots \ldots \ldots \ldots \ldots \ldots \ldots$

3.1 PAGINATION $\ldots \ldots \ldots \ldots \ldots \ldots \ldots \ldots \ldots \ldots \ldots \ldots \ldots \ldots$

3.1 .1 Front Matter ......................... 4

3.1 .2 Main Text ............................. 4

3.2 FRONT MATTER $\ldots \ldots \ldots \ldots \ldots \ldots \ldots \ldots \ldots \ldots \ldots \ldots \ldots \ldots$

3.2 .1 Title Page ........................... 5

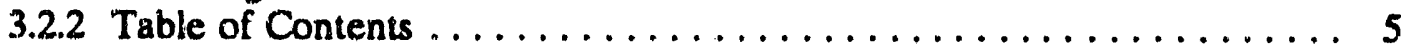

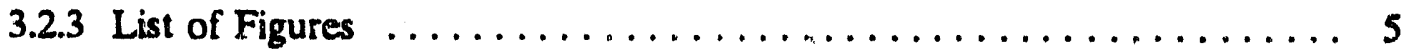

3.2 .4 List of Tables $\ldots \ldots \ldots \ldots \ldots \ldots \ldots \ldots \ldots \ldots \ldots \ldots \ldots \ldots$

3.2 .5 List of Exhibits .......................... 5

3.2 .6 Acknowledgments ........................... 10

3.2 .7 Abstract $\ldots \ldots \ldots \ldots \ldots \ldots \ldots \ldots \ldots \ldots \ldots \ldots \ldots \ldots \ldots \ldots \ldots \ldots$

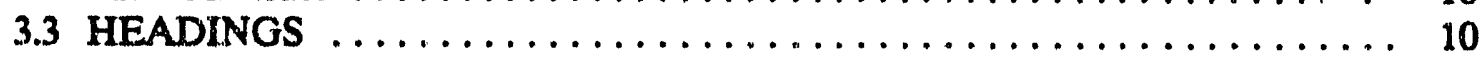

3.4 FOOTNOTES WITHIN TEXT $\ldots \ldots \ldots \ldots \ldots \ldots \ldots \ldots \ldots \ldots \ldots \ldots$

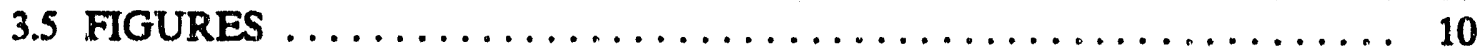

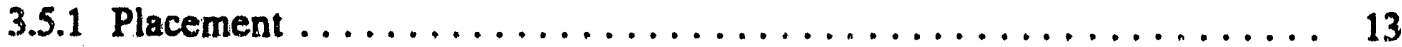

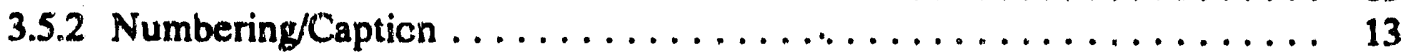

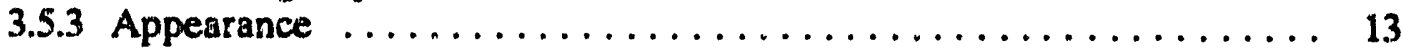

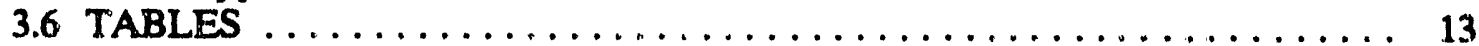

3.6 .1 Placement ............................... 15

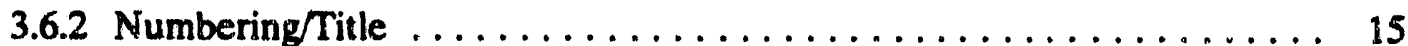

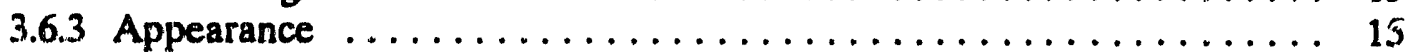

3.6.4 Footnotes/Source Lines $\ldots \ldots \ldots \ldots \ldots \ldots \ldots \ldots \ldots \ldots \ldots \ldots$

3.7 EQUATIONS $\ldots \ldots \ldots \ldots \ldots \ldots \ldots \ldots \ldots \ldots \ldots \ldots \ldots \ldots \ldots \ldots$

3.7.1 Placement and Appearance . . . . . . . . . . . . . . . 19

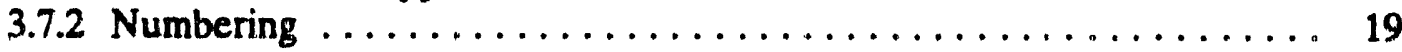

3.7 .3 Where Equations $\ldots \ldots \ldots \ldots \ldots \ldots \ldots \ldots \ldots \ldots \ldots \ldots \ldots$ is

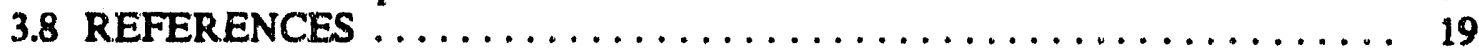


3.8.1 Numbered References $\ldots \ldots \ldots \ldots \ldots \ldots \ldots \ldots \ldots \ldots \ldots, 19$

3.8.2 Author-Date References ........................ 22

3.8.3 Bibliography $\ldots \ldots \ldots \ldots \ldots \ldots \ldots \ldots \ldots \ldots \ldots \ldots \ldots \ldots \ldots \ldots \ldots \ldots \ldots, 23$

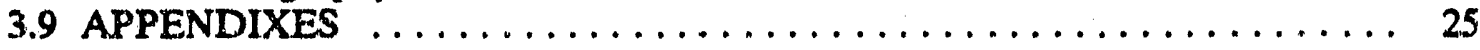

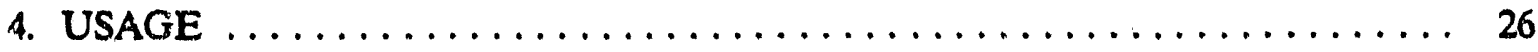

4.1 CROSS-REFERENCING SECTIONS $\ldots \ldots \ldots \ldots \ldots \ldots \ldots \ldots \ldots, 26$

4.2 FORMING PLURALS $\ldots \ldots \ldots \ldots \ldots \ldots \ldots \ldots \ldots \ldots \ldots, 26$

4.3 HYPHENATING COMPOUND WORDS $\ldots \ldots \ldots \ldots \ldots \ldots \ldots 26$

4.5 SPELLING ABBREVIATIONS, INITIALISMS, AND ACRONYMS . . . . 27

5. REFERENCES $\ldots \ldots \ldots \ldots \ldots \ldots \ldots \ldots \ldots \ldots \ldots \ldots \ldots \ldots \ldots \ldots \ldots \ldots \ldots, 28$

APPENDIX A. COMMONLY USED ABBREVIATIONS AND ACRONYMS ... A-1

APPENDIX B. STANDARD EDITING MARKS USED AT ORNL $\ldots \ldots \ldots \ldots$ B-1 


\section{LIST OF EXHIBITS}

Exhibit 1. Sample title page of subcontractor report prepared by the

Trane Company

Exhibit 2. Sample table of contents

Exhibit 3. Two alternative forms for the list of figures $\ldots \ldots \ldots \ldots \ldots \ldots \ldots \ldots \ldots$

Exhibit 4. Two alternative forms for the list of tables $\ldots \ldots \ldots \ldots \ldots \ldots \ldots \ldots \ldots$

Exhibit 5. Explanation and illustration of unnumbered heading form $\ldots \ldots \ldots \ldots \ldots 11$

Exhibit 6. Explanation and illustration of numbered heading form $\ldots \ldots \ldots \ldots \ldots 12$

Exhibit 7. Sample figures with figure captions $\ldots \ldots \ldots \ldots \ldots \ldots \ldots \ldots \ldots$

Exhibit 8. Explanation and illustration of tables $\ldots \ldots \ldots \ldots \ldots \ldots \ldots \ldots \ldots$

Exhibit 9. Sample table with multiline title, vertical lines, and source line . . . . . 17

Exhibit 10. 'Two options for writing "where" lists $\ldots \ldots \ldots \ldots \ldots \ldots \ldots \ldots \ldots$

Exhibit 11. Sample author-date reference list $\ldots \ldots \ldots \ldots \ldots \ldots \ldots \ldots \ldots$ 


\section{ACKNOWLEDGMENTS}

We would like to express our appreciation to Fred Creswick of the Efficiency and Renewables Research Section of the Energy Division at the Oak Ridge National Laboratory for providing the means and moral support for this style guide. We would also like to thank him and Pam Gillis of Publications Division for taking the time to revisw this document and to guide it through its final stages. 


\begin{abstract}
This document has been paraphrased from the ORNL Document Preparation Guide (DPG). It is intended for use by Efficiency and Renewables Research Section, Energy Division, ORNL subcontractors in preparing subcontractor reports so that review and editing effort can be minimized. Topics covered are typing instructions, document format, usage, abbreviations and acronyms, and standard editing marks.
\end{abstract}




\section{INTRODUCTION}

Although subcontractor reports are not required to be written in the Oak Ridge National Laboratory (ORNL) style, several subcontractors have asked for guidance in preparing their reports. The overall appearance and degree of consistency within a document often affects the reader's attitudes about the validity of the contents and the credibility of the author. The purpose of this style guide is to save authors the time and inconvenience of making decisions about how headings, tables, etc. should appear in each document and to assist them in maintaining consistency throughout each document.

The suggestions in this style guide have been paraphrased from the 380-page Document Preparation Guide (DPG), which is used for ORNL documents. Direct quotations from the $D P G$ are followed by their page numbers in parentheses. Most of the guidelines in the DPG and in this guide are geared toward making each document readable and grammatically correct. This guide addresses the areas of typing, format, and usage, and includes an appendix that lists abbreviations, initialisms, and acronyms that recur in subcontractor reports, as well as an appendix that lists the standard editing marks used at ORNL.

A few words are necessary to explain the styie in which this guide was written. We assume that most authors compose their reports on word-processors. Most of the suggestions in this document may be applied to typewritten reports, however, and additional questions may be answered by the editor for the Efficiency and Renewables Research Section at the address below. The verb tense in which most of this guide is written (i.e., should be) was chosen specifically to remind the reader that these are suggestions and guidelines, rather than requirements.

This guide is intended as a tool to enable subcontractors to save time-and money -when revising their reports. Its use is not a substitute for editing. In fact, we strongly recommend that all subcontractor reports be edited by a technical editor who is well versed in the efficiency research and renewables field.

This style guide is intended to be a first edition that will be revised and added to at a later date (e.g., a few years in the future). Suggestions for (1) additional information about typing, format, or usage; (2) clarification of any specific section; or (3) additional abbreviations, initialisms, and acronyms may be submitted to the following address:

Energy Division Publications Office

Oak Ridge National Laboratory

P.O. Box 2008

Bidg. 3147, MS 6070

Oak Ridge, Tennessee 37831 


\section{TYPING INSTRUCTIONS}

If the subcontractor report will be published at ORNL, the final draft must be submitted as camera-ready copy. The text must be printed straight on the page, and the characters and images must be letter-quality and dark and sharp enough to reproduce clearly.

\subsection{FONT}

Font refers to the appearance of the characters in the text.

\subsection{Style}

The DPG recommends the use of serifed fonts because they are "easier to read and comprehend than are sans-serif[ed] fonts such as artisan, letter gothic, and orator" (51). Examples of serifed fonts include

- Dutch Roman, the proportionally spaced font used in this document;

- CG Times, another proportionally spaced font, which prints thinner characters than Dutch Roman; and

- Courier (10 point), which is a nonproportionally spaced font that resembles typewritten text.

Examples of sans-serifed fonts include

- Swiss Roman, a proportionally spaced tont that is virtually indistinguishable from Univers; and

- Univers, another proportionally spaced font, which prints shorter and slightly wider characters than Swiss Roman.

Proportionally spaced fonts are preferred uecause they are easier to read (and more aesthetically pleasing) and because they conserve more space and, thus, paper (and money) than nonproportionally spaced fonts.

\section{Size}

The preferred and most readable size for proportionally spaced fonts is 11 point. If lengthy foctnotes are used in a document, 9 point is recommerided to easily distinguish the footnotes from the primary text. Some authors prefer to distinguish footnotes in this manner regardless of their length. Subscripted and superscripted characters in text and in footnotes must be legible (e.g., " $\mathrm{e}$ "s and "c"s should be easily distinguishable from one another). 


\section{MARGINS}

The left margin should be 1.5 inches; and the top, right, and bottom margins each should be 1 inch. Headings, text, tables, figures, figure captions, footnotes, and page numbers should be placed within these margins.

\subsection{SPACING}

\subsection{Vertical}

Although preliminary drafts may be double-spaced for ease of editing, the final draft should be single-spaced. Word-processor-induced compensation for subscripts and superscripts (i.e., extra space between lines) is often unavoidable and thus is acceptable. No extra line should be placed between paragraphs.

To promote readability, the DPG recommends the following: "If a heading does not have at least two lines of text below it, the heading should be carried over to the next page. The first sentence of a paragraph should not begin on the last line of a page. The last line of a paragraph should not be carried over to the following page, and the last word on a page should not be hyphenated" (5-2).

\subsection{Horizontal}

The first line of each paragraph should be indented five spaces. In an attempt to conserve paper, the Department of Energy also encourages the use of only one space between sentences, as is found throughout this guide. If this practice is followed, only one space should follow colons as well. 


\section{DOCUMENT FORMAT}

"Document Format" refers to the general makeup and organization of the document: in other words, its overall appearance. The purpose of this section is to describe some specific elements of format: pagination, front matter, headings, footnotes, figures, tables, equations, references, and appendixes.

\subsection{PAGINATION}

Page numbers should be the same font style and size as the rest of the text. All pages in a document are counted, even if no page number appears on the page. The standard practice at ORNL is to print reports double-sided and to position each first-order heading on a new page.

\subsubsection{Front Matter}

Lowercase Roman numerals (i.e., i, ii, iii) should be used to paginate the front matter (cf. Sect. 3.2) of a document and should be placed at the bottom center of these pages. The title page is the first page of the front matter, but no page number is displayed on it. Each section of the front matter should begin in an odd-numbered page; therefore, each section that is only one page long should be followed by a page that is completely blank (i.e., there is no page number). If the front matter ends on an odd-numbered page, a blank page should follow this last page and precede the first page of the main text.

\subsubsection{Main Text}

Arabic numbers are used to paginate the main text. Continuous pagination-numbering the pages consecutively throughout the document, rather than by section (e.g., 2-1, 2-2, 3-1)-is preferred because it facilitates finding specific pages. If the author follows the ORNL standard practice of placing each first-order heading on a new page, then he or she should place the page number of each first-order heading at the bottom center of the page. The DPG recommends that the page numbers of the other pages be placed at the top center of these pages, but placing them at the bottom center to be consistent and to facilitate finding pages is acceptable.

While each new first-level heading must begin on a new page, these headings are not required to begin on an odd-numbered (right-hand) page within the body of a report. Do not insert blank pages within the body of a report just so that a first-level heading can begin on an odd-numbered page.

\section{FRONT MATTER}

The front matter of a document includes all material that precedes the main text. The most common front-matter sections included in subcontractor reports are a title page, a table of contents, a list of figures, a list of tables, acknowledgments, and an abstract. 


\section{Title Page}

All of the items on the title page should be centered, except for the ORNL standard technical report number (STRN), which should be flush-right at the top of the page. The title page must include all but not only the following information:

0
0
0
0
0
0

STRN (derived from the subcontract number); report title (and subtitle, if applicable); author(s) name(s); month and year of publication; subcontractor name and complete address; subcontract number; ORNL name, address, and appropriate contract information (cf. Exhibit 1).

Exhibit 1 presents a sample title page for a subcontractor report.

\subsubsection{Table of Contents}

The table of contents should list the headings, subheadings through the third-order level (cf. Sect. 3.3), and corresponding pages (indicated by a dot leader followed by a number) of the front matter, main text, and appendixes. These headings and their corresponding page numbers should exactly match those within the document. Exhibit 2 illustrates a sample table of contents.

\subsection{List of Figures}

A list of figure captions is recommended for reports that have more than five figures. This list should follow the table of contents; and the figure numbers, captions, and page numbers in this list should exactly duplicate those (omitting any source lines, cf. Sect. 3.5.2) of all the figures included in the document. Exhibit 3 presents two options for the appearance of the list of figures.

\subsection{List of Tables}

The list of tables usually follows the list of figures. Like the table of contents and the list of figures, the list of tables should exactly duplicate the table numbers, titles, and corresponding page numbers of all tables in the document. Two options for the appearance of the list of tables are shown in Exhibit 4. Whatever option is chosen for the list of figures should be used for the list of tables.

\section{List of Exhibits}

Exhibits are used less frequently in subcontractor reports than figures and tables, but their use in this guide merits a brief explanation. Exhibits differ from figures in that the latter are illustrations or graphics, whereas the former primarily consist of text that is not in tabular form (cf. the exhibits in this guide). When a doc ament contains exhibits, the list of exhibits should follow the list of tables and should conform to the appearance of the list of figures and list of tables. 


\title{
DEVELOPMENT AND PROOF TESTING OF ADVANCED ABSORPTION REFRIGERATION CYCLE CONCEPTS
}

REPORT ON PHASES I AND IA

\author{
Robert J. Modahl \\ Floyd C. Hayes
}

Published March 1992

Report prepared by

THE TRANE COMPANY

Applied Unitary/Refrigeration Systems Division

Commercial Systems Group

3600 Pammel Creek Road

La Crosse, WI 54601

under Subcontract 86X-17498C

for

OAK RIDGE NATIONAL LABORATORY

P.O. Box 2008

Oak Ridge, Tennessee 37831

managed by

MARTIN MARIETTA ENERGY SYSTEMS, INC.

for the

U.S. DEPARTMENT OF ENERGY

under Contract DE-AC05-84OR21400

Exhibit 1. Sample title page of subcontractor report prepared by the Trane Company. Source: $R$. C. Modahl and F. C. Hayes, Development and Proof Testing of Advanced Absorption Refrigeration Cycle Concepts: Report on Phases I and LA, ORNL/Sub/86-17498/1, Martin Marietta Energy Systems, Inc., Oak Ridge Natl. Lab., March 1982, p. i. 
LIST OF FIGURES $\ldots \ldots \ldots \ldots \ldots \ldots \ldots \ldots \ldots \ldots \ldots \ldots \ldots, \ldots \ldots \ldots$

LIST OF TABLES $\ldots \ldots \ldots \ldots \ldots \ldots \ldots \ldots \ldots \ldots \ldots \ldots \ldots \ldots \ldots \ldots \ldots \ldots \ldots$

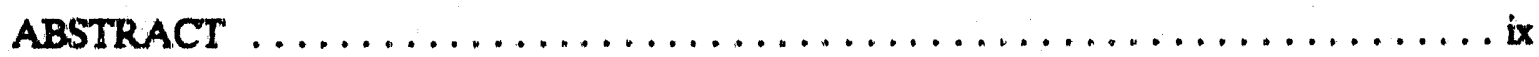

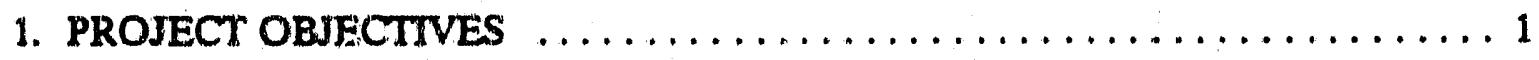

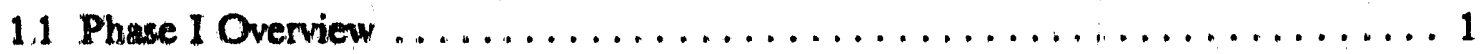

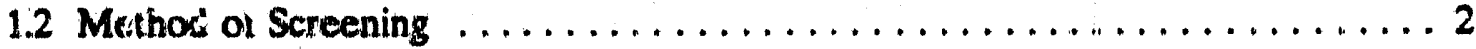

2. SCREENING OF CY LES $\ldots \ldots \ldots \ldots \ldots \ldots \ldots \ldots \ldots \ldots \ldots \ldots \ldots, \ldots \ldots \ldots$

2.1 "Classical" Double-Effect Dycles . . . . . . . . . . . . . . . . . . . 5

21.1 Double-Effect, Dual Pump ......................... 5

2.1.2 Double-Effect, Single Pump, Series Flow ................ 5

2.1.3 Double-Effect, Parallel Flow .........................5 5

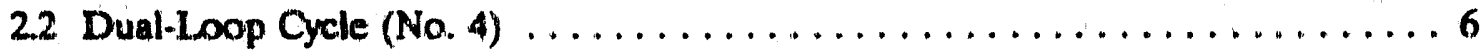

2.3 Two-Pressure, Double-Effect Cycle (No. 5) $\ldots \ldots \ldots \ldots \ldots \ldots \ldots \ldots 6$

2.4 Desorber Resorber Cycle (No. 6) . . . . . . . . . . . . . . . . . . 6

3. CHEMICAL SYSTIEMS AVAILABLE $\ldots \ldots \ldots \ldots \ldots \ldots \ldots \ldots$

3.1 Candidate Qualifications ........................... 9

3.2 Summary of Principal Data Sources Used $\ldots \ldots \ldots \ldots \ldots \ldots \ldots \ldots \ldots 10$

3.21 Methanol ................................. 10

3.22 Lithiusn BromideMethanol $\ldots \ldots \ldots \ldots \ldots \ldots \ldots \ldots \ldots \ldots, 11$

3.23 Zine Bromide/Methanol .............................. 11

4. SELECTION OF CANDIDATE CHEMICAL/CYCLE COMBINATIONS $\ldots \ldots 13$

4.1 Dürring Plots, Crystallization Lines, and Cycle Diagrams $\ldots \ldots \ldots \ldots \ldots 13$

4.2 Preferred-Cycle/Chemical-Pair Combinations $\ldots \ldots \ldots \ldots \ldots \ldots \ldots \ldots$. 8

5. CONCLUUSIONS AND RECOMMENDATIONS $\ldots \ldots \ldots \ldots \ldots \ldots \ldots, \ldots \ldots$

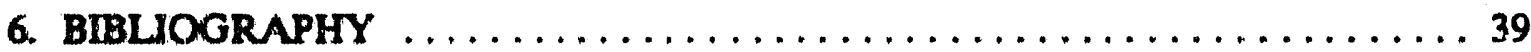

APPENDIX A FIGURES FOR DUAL-LOOP COMPONENTS $\ldots \ldots \ldots \ldots \ldots$ A-1

APPENDIX B. CYCLE CALCULATIONS $\ldots \ldots \ldots \ldots \ldots \ldots \ldots \ldots \ldots$ B-1

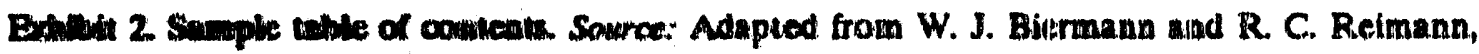

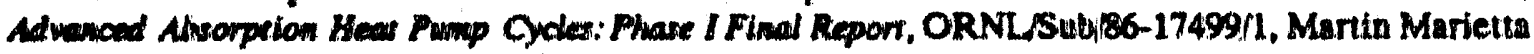
Energy Syatems, Inc, Oak Ridge Natl. Lab., to be published, p. iii. 


\section{LIST OF FIGURES}

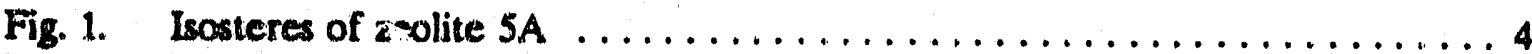

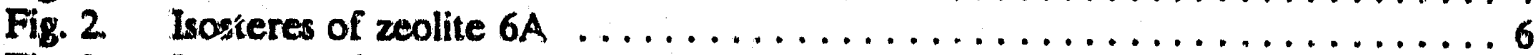

Fig. 3. isusteres of zeolite $7 \mathrm{~A} \ldots \ldots \ldots \ldots \ldots \ldots \ldots \ldots \ldots \ldots \ldots$

Fig. 4. Devpoint $\mathrm{n}$ adsorbent temperatures for zeolite $5 \mathrm{~A} \ldots \ldots \ldots \ldots \ldots \ldots 10$

Fig. A. Test of Temi in isotherm for zeolite $5 \mathrm{~A} \ldots \ldots \ldots \ldots \ldots \ldots \ldots \ldots \ldots \ldots$

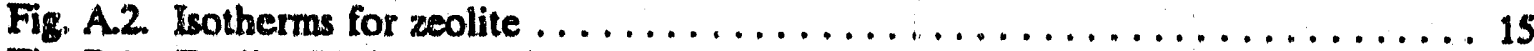

Fig. B.1. Zeolite $5 A$ inventory per bed vs cycle time in relation to maximum allowable inventory for 2-year payback period

20

\section{LIST OF FIGURES}

Figure

1 Isosteres of zeolite $5 A \ldots \ldots \ldots \ldots \ldots \ldots \ldots \ldots \ldots \ldots \ldots \ldots$

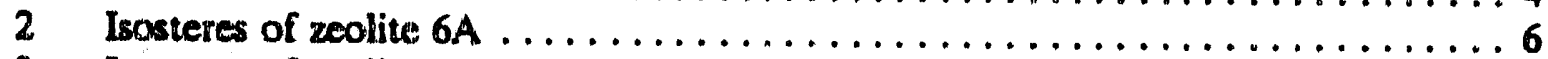

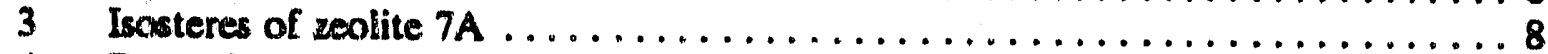

4 Dewpoint vs adsorbent temperatures for zeolite $5 A \ldots \ldots \ldots \ldots \ldots \ldots \ldots \ldots 10$

A.1 Test of Temkin isotherm for zeolite 5 A $\ldots \ldots \ldots \ldots \ldots \ldots \ldots \ldots \ldots \ldots$ 11

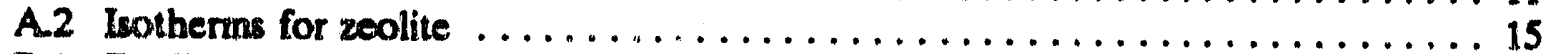

B.1 Zeolite $5 \mathrm{~A}$ inventory per bed vs cycle time in relation to maximism allowable inventory for 2-year payback period

Exwibit 3. Two allemative forms for the list of figures. Source: Adapted from M. R. Ally and J. Braunstein, Absorption Thermadynamics and Economic Comparison of Zeolites $V_{s}$ Metal Hydrides in Industrial Heat Pumpwr, ORNLTM-10648, Martin Marietta Energy Systems, Inc., Oak Ridge Natl. Lab., March 1988, p. v. 


\section{LIST OF TABLES}

Table 1. Summary of previous ternary fluid performance predictions $\ldots \ldots \ldots \ldots 2$

Table 2. Preliminary screening of ternary ammonia/water fluids $\ldots \ldots \ldots \ldots \ldots \ldots$

Table 3. Ternary thid corrosion of mild steel $\ldots \ldots \ldots \ldots \ldots \ldots \ldots \ldots \ldots$

Table 4. Corrosion of mild steel by binary, ternary, and quaternary fluids . . . . 13

Table A.1. Corrosion of various steel alloy by the LiBr ternaty and

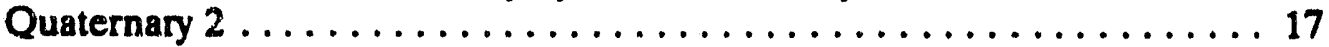

Table A.2. Comparison of electrode weight change $(w)$ and electrochemical

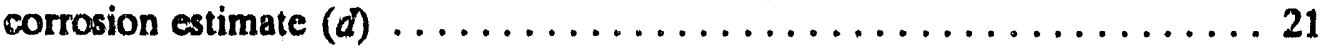

Table B.1. Potential cooling performance for reducing $\mathrm{NH}_{3}$ rectification (Strategy 1) in Generator Absorber Exchange (GAX) cycle . . . . . . . 25

\section{LIST OF TABLES}

Table

1 Summary of previous ternary fluid performance predictions $\ldots \ldots \ldots \ldots \ldots 2$

2 Preliminary screening of ternary ammonia/water fluids $\ldots \ldots \ldots \ldots \ldots \ldots \ldots$

3 Ternary fluid corrosion of mild steel $\ldots \ldots \ldots \ldots \ldots \ldots \ldots \ldots \ldots \ldots$

4 Corrosion of mild steel by binary, ternary, and quaternary fluids $\ldots \ldots \ldots \ldots \ldots 13$

A.1 Corrosion of various steel alloy by the LiBr ternary and

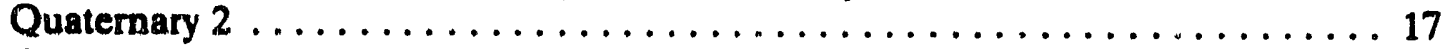

A.2 Comparison of electrode weight change $(w)$ and electrochemical

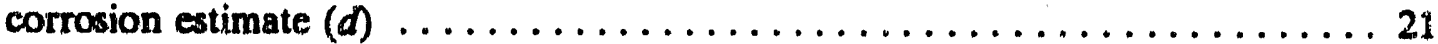

B.1 Potential cooling performance for reducing $\mathrm{NH}_{3}$ rectification (Strategy 1) in Generator Absorber Exchange (GAX) cycle ........... 25

Exhibit 4. Two alternative forms for the list of tables. Source: Adapted from R. H. Reiner and A. Zaluash, Corrosion Screening of Potential Fluids for Ammonia/Water Absorption Cycles, ORNL/CF-92/41, Martin Marietta Energy Systems, Inc., Oak Ridge Natl. Lab., February 1992, p. vii. 


\subsection{Acknowledgments}

An acknowledgments page is optional, but most authors often wish to express their appreciation to individuals or entities who have contributed substantially to the work discussed in the report. Acknowledgments should be limited to one page. Most authors place the Acknowledgments in the front matter, but $i$. could alternatively be placed after the main text and before the Reference List and Bibliography.

\section{Abetract}

An abstract must precede the main text of the document. This section should be a r.aximum of $\mathbf{2 0 0}$ words and should include the following information:

- primary conclusion,

- purpose and nature of the invesitigation.

- description of investigative procedure,

- :esulis, and

- significant numerical data.

\subsection{HEADINGS}

Headings may be either numbered or unnumbered, depending upon the organization and content of the document. Unnumbered heudings may be used in a s scument with few headings and subheadings and with no cross-references (i.e., references to information in other sections). Numbered headings should be used in documents with cross-references for ease of writing, revising, and reading. When numbered headings are used in the main text, front matter headings are not numbered.

Exhibits 5 and 6 provide examples and explanations of unnumbered and numbered headings, respectively.

\subsection{FOOTNOTES WITHIN TEXT}

"Footnotes convey information that is of interest but is aside from the main line of discussion" (4-50). Footnotes within the text should be placed at the bottom of the pinge on which the footnote indicator appears, and they should be indicated in the text and at the bottom of the page by the following symbrols in the following order: ${ }^{*} \uparrow, 7, * *,+7, \#, * * *$, etc. Each footnote should be in paragraph form and followed by a period.

Footnotes within tables are discussed in Sect. 3.6.4.

\subsection{FIGURES}

The main function of a figure is to present data in a readily accessible form. Figures, therefore, should be simple and unified-displaying one suljject without unnecessary detait-and should be self-explanatory and self-contained. Acronyrns should be spelled out and, when applicable, a complete bibliographic reference should be included in the caption. 


\section{FIRST-ORDER HEADDNG}

First-order headings are used for all major sections of the report. Major sections include front matter (e.g.., contents, abstract), main text divisions (chapters or sections), and back matter (e.g., references, bibliography, appendixes). First-order headings are typed in bold capital letters and are centeres between left and right margins. The narrative starts two blank lines below the heaciing and at the paragxaph indent. Subsequent first-order headings are centered two blank lines below the text. In some reports, the author or editor may choose to begin every first-order heading on a new page. If this is done, the page should be a sink page (i.e., one that starts below the level of the top line of the full text page).

\section{SECOND-ORDER HEADNG}

Second-order headings are used to identify major divisions within a chapter or section. They are typed in bold capital letters and start at the left margin. Two blank lines precede and one blank line follows a second-order heading.

\section{Third-Order Heading}

Third-order headings are used to separate the principal topies within a. report division. The first letter of each principal word in the heading is capitalized. The heading starts at the left margin, and the heading is bold. One blank line precedes and one blank line follows a third-order heading.

Fourth-Order Heading Fourth-order headings are used to subdivide the principal topies further if such subdivisions will enhance the report presentation. They are sometimes called paragraph headings and are similar to the third-order headings except that the heading begins with a paragraph indent, a period follows the heading, and the narrative follows the period on the same line. The first letter of each principal word in the heading is capitalized; the entire heading is bold. One blank line precedes the heading.

Use of further subdivisions in the typography-position method is not recommended, and higher-order headings for this method are not defined in this guide.

\footnotetext{
"If the equipment does not have the capability for bold lettering, an underscore can be substituted.
}

Exhibit 5. Explanation and illustration of wnnumbered heading form. Source: Document Preparation Guide, ORNL/RO-1, Martin Marielta Energy Systems, Inc., Oak Ridge Natl. Lab., October 1989, p. 4-72. 


\section{FIRST-ORDER HEADING}

First-order headings are used for a" the major sections of the report. First-order headings are typed in bold capital letters, have a one-digit numerical prefix followed by a period and two spaces, and are centered between the left and right margins. Two blank lines precede and follow a first-order heading.

\subsection{SECOND-ORDER HEADNC}

Second-order headings are used to identify major divisions within a section. A two-digit decimal numerical prefix begins at the left margin, followed by the heading typed in capital letlers. Both the prefix and the heading are bold. The second-order heading is precedisd by iwo blank lines. The narrative is preceded by one blank line and begins with a paragraph indent.

\subsubsection{Thind-Order Heading}

Third-orjer headings are used to separate the principal topies wihin a report division. A three-digit decimal nurierical prefix begias at the left margin and is followed by the heading, which has the first letter of each principal word capitalized; the numerical prefix and all words are bold. One blank line precedes and one blank line follows a third-order hrading. The narrative begins with a paragraph indent.

\subsubsection{Fowrth-Order Headiag}

Fourth-order headings are used to subdivide the principal topies further. Thicy are similar to third. order headings except that they have a four-digit decimal numerical prefix. One blank line precedes and one blank line follows a fourth-order heading. The narrative begins with a paragraph indent.

\section{Fifth-order heading}

If further subdivision is desirable, a nfth-order heading may be used. This heading begins at the left margin, has no numerical prefix, has only the initial letter capitalized, and is bold. One blank line precedes and one blank line follows a tifh-order heading. The carrative begins with paragraph indeat.

Sinth-order beading. This heading is similar to a fifth-order beading except that the beading is paragraph indented, a geriod follows the heading, and the narrative follows the period on the same line. One blank line precedes the heading.

"If the equipmeat does not have the capability for bold lettering, an underscore can be substituted.

Exhibit 6. Explanation and illustration of numbered bcading form. Source: Document Preparation Guide, ORNL/IRO-1, Martin Marictla Encrgy Systems, Inc., Oak Ridge Natl. Lab., October 1989, p. 4-73. 


\subsubsection{Plscement}

Figures should be integrated with the text so that each figure follows its initial call-out as closely as possible. In documents that consist of more figures than text, figures may be grouped at the end of each section or at the end of the document.

Figures should be positioned so that they are in the same direction as the rest of the text and should fit, along with the page number, within the margins. Figures should be designed to fit on one page, but the width of some figures may require them to be rotated $90^{\circ}$ to the rest of the text and to occupy a full page. Such a figure should be positioned with its top at the left margin (of the rest of the text) and its page number in the same position as the page numbers in the rest of the text (top or bottom center).

\subsubsection{Numbering/Caption}

Figures should be numbered consf cutively either throughout the document (e.g., Fig. 1, Fig. 2) or within each section (e.g., Fig. 2.1, Fig. 2.2). Figures should be referred to in text by their numbers rather than their captions. The word, "Figure," is spelled out at the beginning of sentences and is abbreviated elsewhere in the sentence.

Figure captions should be concise and complete. The word, "Figure,"is abbreviated and is followed by the figure number and a period, which is followed by the caption. Captions should be written in boldface type in initial caps. (i.e., with the first letter of the first word and of proper nouns capitalized and with abbreviations that normally contain capital letters written as such). Captions should be centered and placed below the figure, and the width of the caption should not exceed the width of its figure. All figure captions should end with a period, and captions that occupy more than one line should be single-spaced and written in paragraph form.

Figures that have more than one image area should be have each area labeled separately, and the caption should include an explanation or description of each. The caption for Exhibit 7 illustrates how this type of figure caption should be written: the labels may appear inside or outside the image areas. Figures that have been obtained from another source must include a full bibliographic reference at the end of the caption, as shown in Exhibit 7a. Source lines and descriptions of different images within a figure are not set in boldface type.

\subsubsection{Appearance}

The parts of each image should be labeled clearly. For example, the label of the $y$-axis of a graph should be placed parallel to that axis rather than at the top of the graph. Initial caps or all caps may be used for labels, legends, or other explanatory notes, but consistency must be maintained within each figure and throughout the document.

\subsection{TABLES}

Tables function in a manner similar to figures in that they both present data in a readily accessible form. Tables, therefore, should also be simple, unified, self-contained, and selfexplanatory; acronyms should be spelled out and source lines should be provided (cf. Sect. 3.6.4). 

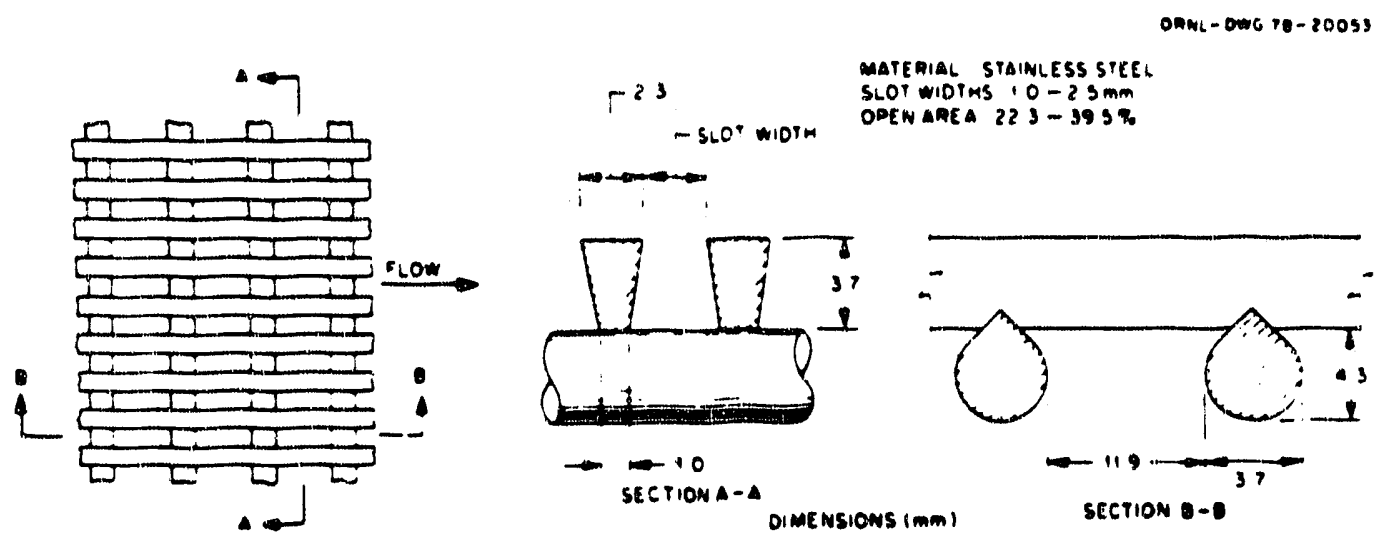

Fig. 4.1. Characteristics of Aat wedge-wire screen panels used in the Tennessee Vallcy Anthority bydraulic tests. Source: S. Vigander, "Current TVA Work on the Fluid Mechanies of Screens with Very Small Openings for the Exclusion of Larvae at Power Plant Cooling-Water Intakes," presented at the Workshop on Larval Exclusion Systems for Power Plant Cooling Water Intakes, Feb. 7-8, 1978, San Diego; to be published in the proceedings.

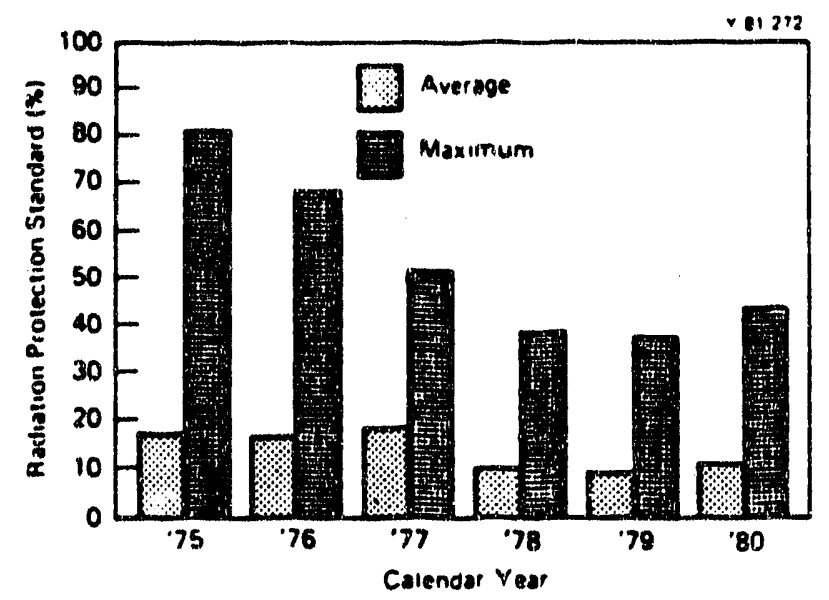

Fig. 45. Uraxium body-count results sbow." ing maximum exposure less than $50 \%$ of the rediation protection standard for the third year.

Exhibit 7. Sample figures with ligurc captions. (a) Figure with $x$ - and $y$-axes labeled, $(b)$ figure caption with a source line. Source: Document Preparation Guide, ORNLIRO-1, Martin Marietta Energy Systems, Inc., Oak Ridge Natl. Lab., October 1989, pp. 4-16 and 4-21. 


\subsubsection{Placement}

The same principle for figure placement applies to table placement. Tables can be integrated into the text and should follow as closely as possible their first point of reference. They can alternatively be grouped at the end of each section or the end of the document if there are more tables than text.

Likewise, the philosophy underlying figure orientation applies to tables. "Tables should be oriented in the same direction as the text when possible" (DPG 1989, 4-34) and should fit, along with the page number, within the margins. When the width of a table requires it to be rotated $90^{\circ}$ to the rest of the text and to occupy a full page, it should be positioned with the top of the table at the left margin (of the rest of the text) and the page number placed in the same position as the page numbers in the rest of the text (top or tottom center). Tables that are continued on subsequent pages should indicate this [i.e., Table 1. (Continued)]. In order to fit a table on one page, it may be set in smaller type than 11 point; but characters, superscripts, and subscripts must be legible.

\subsubsection{Numbering/Title}

If figures are numbered consecutively throughout the document (e.g., Fig. 1, Fig. 2), then the tables should be numbered consecutively; if the figures are numbered by section (e.g., Fig. 2.1, Fig. 2.2), then the tables should be numbered in this manner. Tables should be referred to in text by their numbers rather than their titles.

Table titles should be as brief and complete as possible; thus, acronyms should be spelled out in the title. Titles should be written in boldface type in initial caps. The table number, followed by a period, appears on the same line as the title (Exhibit 8 ). Table titles should be centered and placed above the table, and the width of the title should not exceed the width of its table. Titles that occupy more than one line should be single-spaced and should be written in inverted pyramid style with each line centered above the table (Exhibit 9). No final punctuation is used with table titles.

\subsubsection{Appearance}

\subsubsection{Columns}

Column heads should be set in boldface type and written in initial caps. Each head should be single-spaced (if more than one line) and centered above its column, with units of measurement abbreviated, enclosed in parentheses, and centered under the column head.

Data within each column should be aligned on the decimal point, comma, or dash if most of the numbers are in "the same unit of measure" (DPG 1989, 4-37). If most of the numbers are not in the same unit of measure, they should be aligned on the left. Arithmetic signs of operation (e.g.,,,+- \pm ) are aligned as well. 


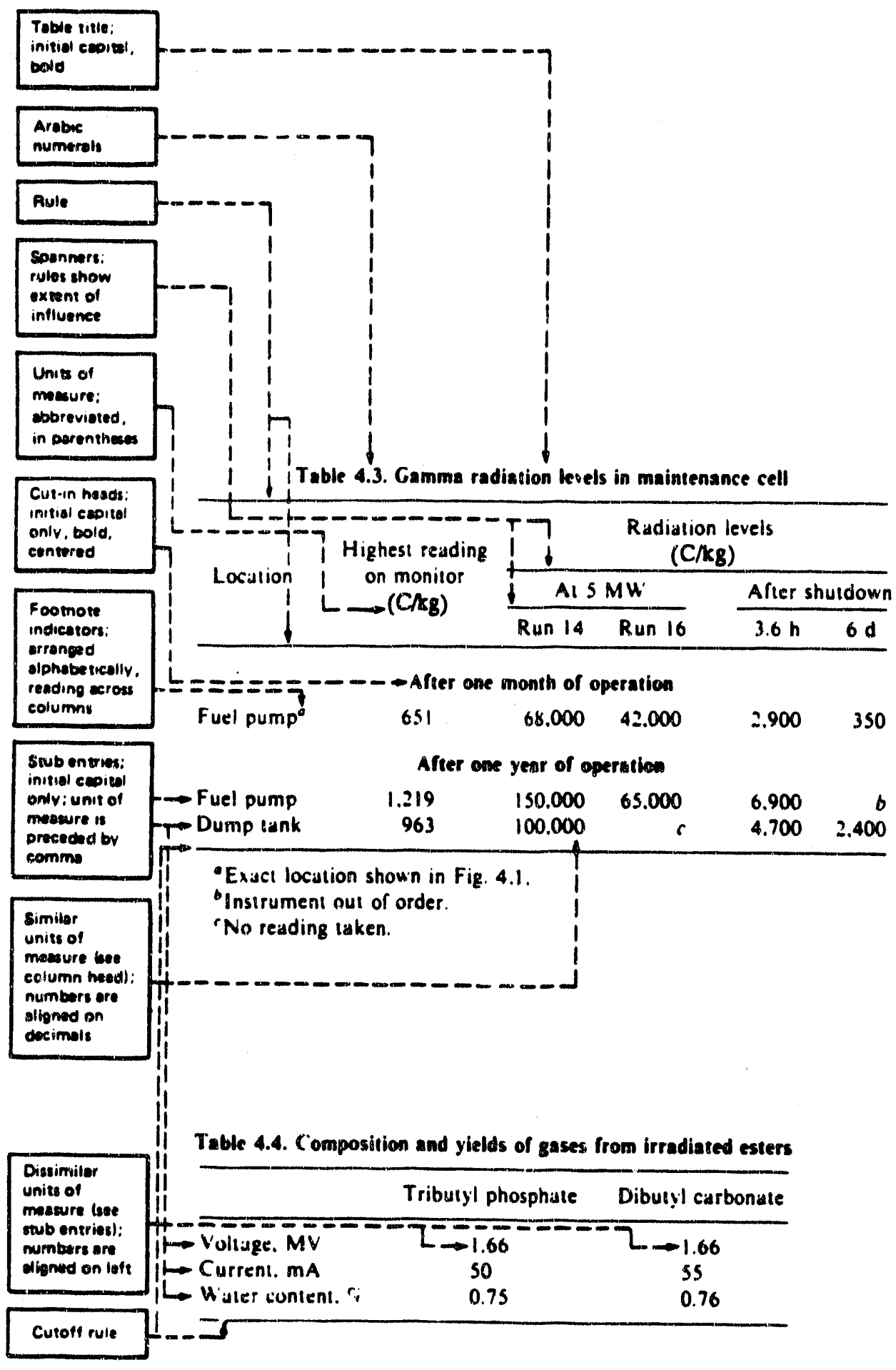

Exhibit 8. Explanation and illustration of tables. (a) Table with multilevel column heads, decimal alignment, and footnotes; (b) lable with left alignment. Source: Document Preparation Guide, ORNL/IRO-1, Martin Marietta Energy System:, inc., Oak Ridge Natl. Lab., October 1989, p. 4-33. 
Table 4.12. Mewn mineral comtent of mutriewts and other paranaters iv water hyaciath from varions becations (dry weight measure)

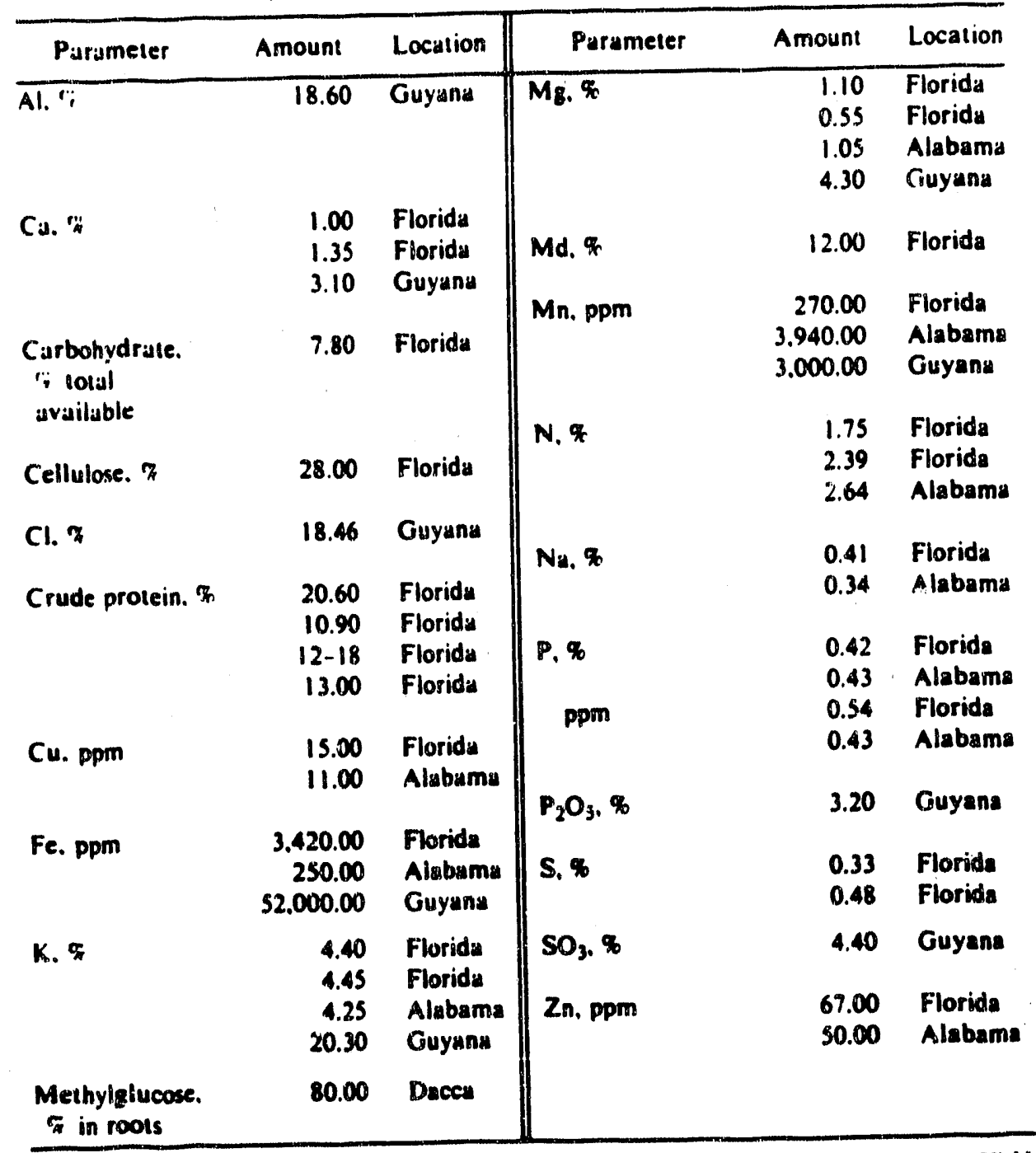

Source: Reprinted with permiation Irem E. S. Dal Fomen "Water Hyeciath Dionsen Yiold

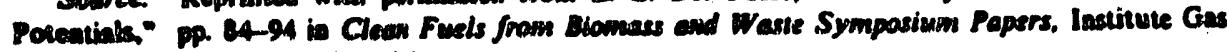
Testool. Chiciege, Table 3, p. 4.

Exhibit 9. Sample table with mulciline title, vertical lines, and gource line. Source: Document Preparation Guide, ORNL/RO-1, Martin Marietta Energy Systems, Inc., Oak Ridge Natl. Lab., October 1989, p. 4-40. 


\subsubsection{Rows}

In addition to the vertical alignment described in Sect. 3.6.3.1, horizontal alignment (across rows) must be maintaines. Each column entry must be aligned with the first line of the row head ("stub item"in Exhibit 8). Stub items are set in initial caps and are followed by a comma and the abbreviated units of measurement (when applicable). Stub items are singlespaced, and the second (third, etc.) line of a multiline stub item should be indented.

\subsubsection{Rules}

Although the layout and contents of a table will det armine how rules, or lines, are used, rules should be kept to a minimum. Solid thin lines are recommended because they minimize clutter more effectively than dashed, dotted, thick, or double lines. Vertical rules should not be used unless absolutely necessary ( $c f$. Exhibit 9 ); vertical alignment creates a straight vertical line in each column, making this type of rule redundant. Horizontal rules should be no wider than the width of the table. Whenever possible, they should be placed (1) between the table title and the body of the table, (2) between the column heads and the column entries, (3) between levels of column heads (called "spanners"in Exhibit 8), and (4) below the last row of the table.

\subsubsection{Footnotes/Source Lines}

Unlike footnote indicators $w$, hin the text, which are symbols, footnote indicators within tables are lowercase italic letters. These proceed in alphabetical order from left to right across each row, from the first to the last row of the table. Footnote indicators should be superscripts unless they constitute an entry, in which case they should be the same size as the other entries. Footnotes to the trible title are discouraged. The actual footnotes should be placed below the cutoff rule of the table (Exhibit 8).

A table or data within a table that have been taken from another source must be acknowledged by a source line, which includes a full bibliographic entry and which indicates whether or not the table or data have been "Adapted from" or "Reprinted with permission from" another source. The source line should appear below the cutoff rule and below any footnotes (Exhibit 9).

\subsection{EQUATIONS}

A simple equation that is not cross-referenced may be embedded in the line of text. A complex or lengthy equation, however, should be displayed on a line by itself; any equation that is cross-referenced must be displayed, numbered, and referred to in text by its number. 


\subsubsection{Placement and Appearance}

Each displayed equation should follow its initial in-text reference; that is, it should be displayed after the sentence in which this reference appears. One blank line should precede and follow the displayed equation, and the equation should be centered horizontally. One space should be placed between the end of the equation and the punctuation mark that follows.

\subsection{Numbering}

Equations should be numbered in the same manner as the figures and tables, either consecutively throughout the document or by section. The word, "Equation' is spelled out at the beginning of a sentence and is abbreviated [i.e., Eq. (1), Eqs. (1) and (2)] elsewhere. The equation number is enclosed in parentheses and is flush-right to the vertical center of the equation (cf. Exhibit 10).

\subsection{3 "Where" Equations}

Equations often contain variables that require definition. This is accomplished with a "where" list. Exhibit 10 illustrates two ways of writing "where" lists. In using the second option, many authors align the "where" entries on the equal sign to make them more readable.

\subsection{REAFERENCES}

Numbered references or author-date references are the most common types that occur in subcontractor reports. One of these reference styles should be used consistently throughout each document.

\subsubsection{Numbered References}

\subsubsection{In text}

Superscript Arabic numbers are used in text to indicate that material has been derived from another source. Each number should be placed at the end of the syntactical unit in which the material occurs (e.g., end of the sentence). ${ }^{1}$ When referring to a specific reference number within the text, the word "reference" is capitalized and spelled out if it occurs at the beginning of the sentence (e.g., Reference 1 concludes. . . .") and is in lowercase letters and abbreviated when it occurs in the middle of a sentence (e.g., as found in ref. 1.).

\subsubsection{Reference list}

The reference list is placed after the last chapter of the main text and is given a firstorder (and numbered, when applicable) heading. The references are listed in order by number, and many authors include the page number of the reference to guide the reader directly to the material (as in the following examples 1 and 2). The following examples of numbered references were adapted from the DPG (4-45-4-49). 
"Displayed" equation with simple, ran-m "molbere" liat

$$
x_{k}(\beta)=E_{0} \sum_{n=k}^{\infty} \frac{\beta}{n^{3}}\left(1-\frac{\beta}{n^{2}} e\right) \frac{\beta}{n^{2}} .
$$

where $E_{0}$ is the kinetic energy of translation of a molecule at $0^{\circ} \mathrm{C}, n$ is the number of gas molecules per cubic centimeter $a 0^{\circ} \mathrm{C}$, and $e$ is the potencial energy.

Equation with more complicated "abere" list; for "where" Hist, mote aligmenent on left

$$
\operatorname{COP}_{A V G}=\frac{\sum_{i=1}^{N}\left(Q H_{F_{1}}\right) r_{i}}{\sum_{i=1}^{N}\left(W_{F_{1}}\right) r_{i}}=\operatorname{COPSS}\left(1-m_{2} / 100\right)
$$

where

COPAvG $_{A}$ average COP calculated over given frosting period,

$Q H_{F_{1}}=$ average heating capacity under frosting conditions for time $\tau_{\text {, }}$,

$W_{F_{1}}=$ average power usage of heat pump under frosting conditions for time $\tau_{1}$

COPss = steady-state COP,

$N=$ integral number of time increments,

$m_{2}=$ coefficient expressing the percentage loss in steady-state COP.

Note that in a "wirere" list, an "and" is not used before the last entry.

Euchibit 10. Two options for writing "whcre lists. Source: Document Preparation Guide, ORNL/RRO-1, Martin Marietta Encrgy Systems, Inc., Oak Ridge Natl. Lab., October 1989, pp. 6-48 and 6-49. 
Books

1. B. E Hobbs, W. D. Means, and P. F. Williams, An Outline of Stricctural Geology, Wiley, New York, 1976, p. 13.

More than three authors

2. D. A Cadbury et al, A Computer Mapped Mlora. A Study of the Cownty of Wanwicktehire, Academic Press, New York, 1971, pp. 13-14.

Journel Articles

Authored article

3. H. J. Rose and D. Sinclair, "A Search for High-Energy Alpha Particles from Superbeavy Ekements," J. thys. G 5, 781-96 (June 1979).

Article with a corporate author

4. Environmental Protection Agency, "General Pretreatment Regulations for Existing and New Sources of Pollution," Fed. Regist. 43 (PL. 4), 27736-13 (June 26, 1978).

Proceding

Article in a proceedings

5. G. F. Tape, Wational Policy on Penceful Uses of Nuclear Explosives," pp. 3-9 in Education for Peacaful Uxes of Muclear Explostues, proceedings of the Symposium on Education for the Peaceful Uses of Nuclear Explosives at the University of Aribona, Tucson, March 31-April 2, 1969, od. L E Weaver, Univ. Arizoma Presil, Tucson, 1970.

Proceudings as secondary title

6. P. S. Nutman and B. Mosse, eds., Symbiotic Associations. Thirteenth Symyrosium of the Socticty for Ceneral Microbiblogy Held at the Royal Institution, London, April 1963, Cambridge Univ. Press, New York, 1963.

Article in a proceedings us a journal

7. E M. Harrell II, "Ceneralizations of Temple's Inequality," Proc. Am. Math. Soc. 69, 271-76 (Misy 1978).

Reports

Numbered report

8. C. T. Hisu, Investigation of an Ejecror Heat Pump by Analytical Methods, ORNL/CON-144, Martin Marietta Energy Systems, Inc., Onk Ridge Natl. Lab., July 1984. 


\section{Unnumbered report}

9. U.S. Nuclear Regulasory Commission: Annual Report 1976, U.S. Nuclear Regulatory Commission, 1976.

Patents

10. L. O. Stebbins, "Ultrasonic Inspection Transducer Assembly," U.S. patent 3,248,933, May 16, 1963.

Special Materials

\section{Personal communication}

11. P. Peterson, U.S. Department of Health, Education, and Welfare, Washington, D.C., [letter, telephone call, etc.] to R. L. Cline, Colorado State Department of Health, Denver, July $27,1970$.

\section{Dissertations}

12. J. B. Eskew, "Flame Spectrometric and Solvent Extraction Studies," Ph.D. dissertation, The University of Tennessee, Knoxville, 1971.

\section{8 .2 Autbor-Date References}

The author-date reference system closely resembles the standard numbered reference system. The primary difference between the two styles is the transposition of the first and last names of the author and the movement of the date of publication from the end of the reference to a position following the author's name. The numbered reference system is preferred, although the author-date system may be used in some situations. According to the $D P G$, the author-date system may be used "when it is necessary to separate substantive notes from references and bibliographic entries in heavily documented publications" (C-47).

\subsubsection{In text}

When the author-date method is used, the author's last name (authors' last names, if there are two or three authors; author's last name et al., if there are more than three authors; or the title, if no author's name is given) and year of publication are used instead of superscript numbers. These items are enclosed in parentheses and precede any punctuation that follows. To distinguish between references with the same author and the same year, a lowercase letter is added in text and in the reference list to the year of each (e.g., Jones 1987a). Authors who wish to include specific page numbers in these references should place them after the date (e.g., Jones 1987a, 19). 


\subsection{Reference list}

The reference list for author-date references is also given a first-order (and numbered, when applicable) heading. Such a list differs from that of numbered references in that (1) references are neither numbered nor listed in the order of their appearance in the main text but are alphabetized; and (2) the first line of each reference is flush-left, and subsequent lines are indented. Exhibit 11 is an alphabetized list of the references from Sect. 3.8.1.2 that have been put in the author-date form.

\subsection{Bibliography}

Because the reference list includes only material that has been referenced in the text, many authors include a bibliography to direct the reader to other pertinent literature. The bibliography should follow the reference list and should be given the first-order heading (cf. Sect. 3.3), SELECTED BIBLIOGRAPHY. The bibliography should not be numbered and should resemble an author-date reference list. 


\section{REFERENCES}

Cadbury, D. A, et al. 1971. A Computer-Mapped Flora. A Study of the County of Wanwickshire, Academic Press, New York.

Environmental Protection Agency June 16, 1978. "General Pretreatment Regulations for Existing and New Sources of Pollution," Fed. Regist. 43 (Pt. 4), 27736-73.

Eskew, J. B. 1971. "Flame Spectrometric and Solvent Extraction Studies," Ph.D. dissertation, The University of Tennessee, Knoxville.

Harrell II, E. M. May 1978. "Generalizations of Temple's Inequality," Proc. Am. Math. Soc. 69, 271-76.

Hobbs, B. E., Means, W. D., and Williams, P. F. 1976. An Outline of Structural Geology, Wiley, New York.

Hsu, C. T. July 1984. Investigation of an Ejector Heat Pump by Analytical Methods, ORNL/CON-144, Martin Marietta Energy Systems, Inc., Oak Ridge Natl. Lab., July.

Nutman, P. S. and Mosse, B., eds. 1963. Symbiotic Associations. Thirteenth Symposium of the Society for General Microbiology Held at the Royal Institution, London, April 1963, Cambridge Univ. Press, New York.

Peterson, P. July 27, 1970. U.S. Department of Health, Education, and Welfare, Washington, D.C., [letter, telephone call, etc.] to R. L. Cline, Colorado State Department of Health, Denver.

Rose, H. J. and Sinclair, D. June 1979. "A Search for High-Energy Alpha Particles from Superheavy Elements," J. Phys. G 5, 781-96.

Stebbins, I. O. May 16, 1963. "Ultrasonic Inspection Transducer Assembly," U.S. patent $3,248,933$.

Tape, G. F. 1970. "National Policy on Peaceful Uses of Nuclear Explosives," pp. 3-9 in Education for Peaceful Uses of Nuclear Explosives, proceedings of the Symposium on Education for the Peaceful Uses of Nuclear Explosives at the University of Arizona, Tucson, March 31-April 2, 1969, ed. L. E. Weaver, Univ. Arizona Press, Tucson.

U.S. Nuclear Regulatory Commission: Anniual Report 1976. U.S. Nuclear Regulatory Commission.

Exhibit 11. Sample author-date reference list. Source: Adapted from the Documcnt Preparation Guide, October 1989. ORNL/RO-1, Martin Marietta Energy Systems, Inc., Oak Ridge Natl. Lab., 445-4-49. 


\subsection{APPENDIXES}

"Appendixes contain detailed information that is not essential to a basic understanding of the work and the results obtained but that may be helpful to readers. Detailed test data, engineering drawings of component parts, graphs, information on a long series of tests, lengthy mathematical derivations, or detailed analytical procedures would be appropriate material for an appendix" (DPG 1989, 4-51).

Each appendix should be given a first-order heading (Sect. 3.3). More than one set of information should be divided into separate appendixes, and each should be labeled Appendix A, Appendix B, etc. If only one appendix is included in a document, it should be labeled simply Appendix. Even if tables, figures, exhibits, and equations are numbered consecutively throughout the main text, they should be numbered separately when they occur within each appendix [e.g., Fig. A.1, Eqs. (B.1) and (B.2)]. 


\section{USAGE}

Most usage questions can be answered by consulting a standard grammar handbook. The sections that follow address usage questions that can cause a reader to misunderstand an author's meaning. Following the suggestions in this section will save the author time when revising the draft. The purpose of this section is to provide examples of the spelling, punctuation, abbreviation, etc., of words and phrases commonly found in subcontractor reports. Specifically, this section discusses cross-referencing sections; forming plurals; hyphenating compound words; and spelling abbreviations, initialisms, and acronyms.

\subsection{CROSS-REFERENCING SECTIONS}

Clarity of cross-references to other sections within the document facilitates reader comprehension of the material presented. The divisions of ORNL technical reports are referred to as "sections" rather than "chapters." The word or abbreviation for "section" is capitalized when followed by the section number (e.g., Section 1, Sect. 1) but not when used generically (e.g., "in this section"). The word is spelled out at the beginning of sentences (e.g., Section 1, Sections 1 and 2) and is abbreviated when it occurs elsewhere in the sentence (e.g., Sect. 1, Sects. 1 and 2). When cross-referencing material that is in another section, authors should specifically denote by number the section in which the material can be found, rather than stating that it is "above," "below," "earlier," or "later" in the report.

\section{FORMING PLURALS}

The plurals of most acronyms and numbers are formed by adding the letter "s" without preceding it with an apostrophe (e.g., 1900s, COPs). The plurals of single letters and of abbreviations ending in periods are formed with an apostrophe (e.g., U's, Ph.D.'s).

The following are exceptions: Sects., Refs., Figs., Eqs.

\subsection{HYPHENATING COMPOUND WORDS}

Both The Chicago Manual of Style (163) and the DPG (6-11) point out the absence of hard-and-fast rules for hyphenating compound words. The Chicago Manual of Style notes a trend to minimize the use of hyphens in compound words and to spell them as two words without a hyphen or as one word. Each compound word should, nonetheless, be consistently spelled (with or without a hyphen) throughout a document. The following suggestions are general guidelines derived from The Chicago Manual of Style and the DPG.

- No hyphen should be inserted between an adverb that ends in -ly and the word it modifies.

- Hyphens are not used when spelling chemical compounds (e.g., lithium bromide, carbon dioxide). 
- When a compound adjective begins with a single letter, a hyphen is inserted between this letter and the word that follows it (e.g., U-shaped tube, Y-joint).

- A hyphen is inserted between a number and an abbreviated unit of measure that follows it when this compound adjective phrase modifies a noun (e.g., 2-m opening, 7-m-deep pit). Hyphens are not used when the compound adjective phrase is not followed by a noun (e.g., the board was $2 \mathrm{~m}$ ).

- Hyphens are not used in a compound adjective that has a letter or number as its second element (e.g., type 347 stainless steel, class B construction).

- Hyphens should be used in compound adjectives or with prefixes to avoid confusion. For example, a fast sailing ship could be interpreted a fast, sailing ship or a fast-sailing ship (The Chicago Manual of Style 1982, 163-164); unionized should not be used for unionized.

\subsection{SPELLING ABBREVIATIONS, INITIALISMS, AND ACRONYMS}

All initialisms and acronyms must be defined before they appear in the text, and they must appear in parentheses immediately after their definitions [e.g., Document Preparation Guide (DPG)]. In lengthy reports, authors may wish to define initialisms and acronyms in each section or to insert a list of recurring abbreviations, initialisms, and acronyms between the list of tables (or exhibits) and the abstract.

Although no hard-and-fast rules exist for spelling abbreviations, initialisms, and acronyms, the current trend is to capitalize and omit punctuation from initialisms and acronyms and to omit punctuation from abbreviations when such an omission will not lead to confusion (e.g., the abbreviation for inch, in., is punctuated to distinguish it from the word, in). Articles (a, an, the) should not precede initialisms and acronyms that are used as nouns, but they may be necessary to make initialisms and acronyms used as adjectives more readable. The $D P G$ offers the following example:

Most activities at ORGDP were performed directly for DOE.

The ORGDP powerhouse was built by the DOE subcontractor (6-65).

Standard usage of the articles "a" and "an" applies to their use with initialisms and acronyms. If the initial sound of the following initialism or acronym is a consonant, "a" should be used; if it is a vowel sound, "an" should be used. The DPG offers the following examples of articles used with two acronyms and an initialism, respectively: a NASA report, a LOCA text, an FPS form (6-2).

The solidus $(/)$ is used to indicate the quotient of two or more abbreviated units of measure, but only one solidus should be used in each abbreviation (e.g., newton per square meter $=\mathrm{N} / \mathrm{m}^{2}$, newton per second per square meter $=\mathrm{N} \cdot \mathrm{s} / \mathrm{m}^{2}$ ). 


\section{REFERENCES}

1. M. R. Ally and J. Braunstein, Absorption Thermodynamics and Economic Comparison of Zeolites Vs Metal Hydrides in Industrial Heat Pumps, ORNL/TM-10648, Martin Marietta Energy Systems, Inc., Oak Ridge Natl. Lab., March 1988.

2. W. J. Biermann and R. C. Reimann, Advanced Absorption Heat Pump Cycles: Phase I Final Report, ORNL/Sub/86-17499/1, Martin Marietta Energy Systems, Inc., Oak Ridge Natl. Lab., to be published.

3. The Chicago Manual of Style, 13th ed., The University of Chicago Press, Chicago and London, 1982.

4. Document Preparation Guide, ORNL/IRO-1, Martin Marietta Energy Systems, Inc., Oak Ridge Natl. Lab., October 1989.

5. J. T. Miller, Abbreviations, Acronyms, and Initialisms Frequently Used by Martin Marietta Energy Systems, Inc., Oak Ridge Natl. Lab. (not for external distribution), [n.d.].

6. R. C. Modahl and F. C. Hayes, Development and Proof Testing of Advanced Absorption Refrigeration Cycle Concepts: Report on Phases $I$ and IA, ORNL/Sub/86-17498/1, Martin Marietta Energy Systems, Inc., Oak Ridge Natl. Lab., March 1992.

7. R. H. Reiner and A Zaltash, Corrosion Screening of Potential Fluids for Ammonia/Water Absorption Cycles, ORNL/CF-92/41, Martin Marietta Energy Systems, Inc., Oak Ridge Natl. Lab., February 1992. 


\section{APPENDIX A \\ COMMONLY USED ABBREVIATIONS AND ACRONYMS}

The following is a list of abbreviations, initialisms, and acronyms commonly used in subcontractor reports. It is not meant to be an exhaustive list. Standard abbreviations for metric units are used at ORNL and thus have not been included in this list. This list was derived from the abbreviations, initialisms, and acronyms list compiled by J. T. Miller.

\begin{tabular}{|c|c|}
\hline $\begin{array}{l}\text { Abbreviation, } \\
\text { Initialism, } \\
\text { or Acronym }\end{array}$ & Word or Phrase \\
\hline A & ampere \\
\hline $\mathrm{A} / \mathrm{C}$ & air conditioner/conditioning \\
\hline ac & alternating current \\
\hline ARI & Air-Conditioning and Refrigeration Institute \\
\hline ASChE & American Society of Chemical Engineers \\
\hline ASHRAE & $\begin{array}{l}\text { American Society of Heating, Refrigerating, and Air-Conditioning } \\
\text { Engineers }\end{array}$ \\
\hline ASME & American Society of Mechanical Engineers \\
\hline $\begin{array}{l}\text { ASTM } \\
\text { av }\end{array}$ & $\begin{array}{l}\text { American Society for Testing and Materials } \\
\text { average }\end{array}$ \\
\hline bhp & brake horsepower \\
\hline Btu & British thermal unit \\
\hline Btu/h & British thermal units per hour \\
\hline${ }^{\circ} \mathrm{C}$ & $\begin{array}{l}\text { Celsius (no space between number, degree, and abbreviation; i.e., } \\
1^{\circ} \mathrm{C} \text { ) }\end{array}$ \\
\hline cf. & compare \\
\hline COP & coefficient of performance \\
\hline d & day \\
\hline dc & direct current \\
\hline $\operatorname{deg}$ & degree (when not preceded by number, otherwise use ${ }^{\circ}$ ) \\
\hline DÖE & U.S. Department of Energy \\
\hline $\begin{array}{l}\text { e.g. } \\
\text { EMP }\end{array}$ & $\begin{array}{l}\text { exempli gratia (for example) (use only in parentheses or footnotes) } \\
\text { electromagnetic pulse }\end{array}$ \\
\hline EPA & U.S. Environmental Protection Agency \\
\hline $\begin{array}{l}\text { EPRI } \\
\text { et al. }\end{array}$ & $\begin{array}{l}\text { Electric Power Research Institute (Palo Alto, California) } \\
\text { et alii (and others) }\end{array}$ \\
\hline & \\
\hline FPSE & $\begin{array}{l}\text { degrees Fahrenheit (no space; e.g., } 1^{\circ} \mathrm{F} \text { ) } \\
\text { free-piston Stirling engine }\end{array}$ \\
\hline & foot or feet \\
\hline
\end{tabular}




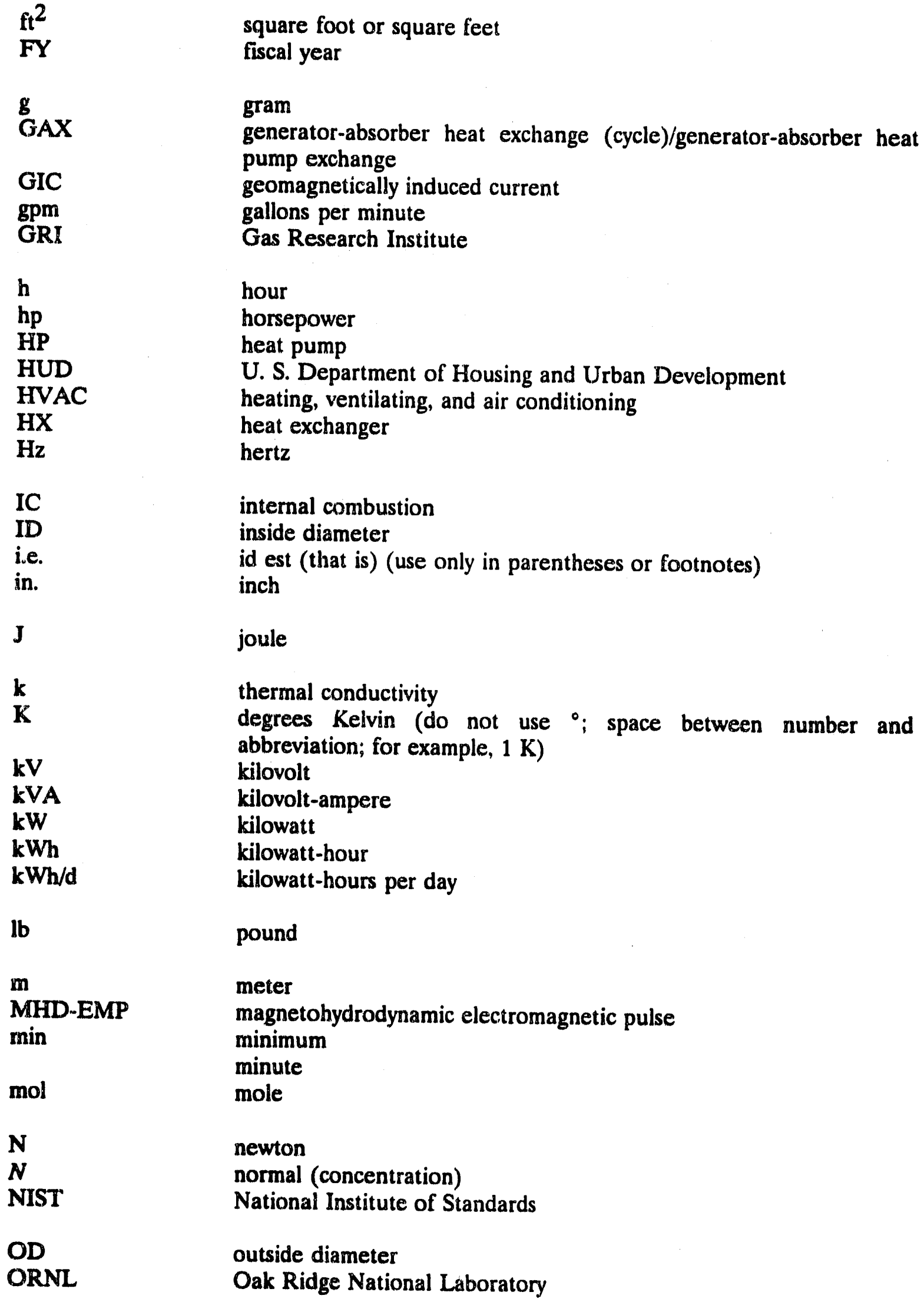

ID

i.e.

in.

J

hour

horsepower

heat pump

U. S. Department of Housing and Urban Development

heating, ventilating, and air conditioning

heat exchanger

hertz

internal combustion

inside diameter

id est (that is) (use only in parentheses or footnotes)

inch

joule

k

$\mathbf{R}$

kV

kVA

kW

kWh

$k W h / d$

thermal conductivity

degrees Kelvin (do not use ${ }^{\circ}$; space between number and abbreviation; for example, $1 \mathrm{~K}$ )

kilovolt

kilovolt-ampere

kilowatt

kilowatt-hour

kilowatt-hours per day

lb

pound

MHD-EMP

$\min$

mol

meter

magnetohydrodynamic electromagnetic pulse

minimum

minute

mole

$\mathbf{N}$

newton

$N$

NIST

normal (concentration)

National Institute of Standards

OD

ORNL

outside diameter

Oak Ridge National Laboratory 


$\begin{array}{ll}\begin{array}{l}\text { \% } \\ \text { psi } \\ \text { psia }\end{array} & \begin{array}{l}\text { percent } \\ \text { pounds per square inch } \\ \text { pounds per square inch, absolute }\end{array} \\ \text { R\&D } & \begin{array}{l}\text { research and development } \\ \text { refrigerator-freezer } \\ \text { RF }\end{array} \\ \text { RH } & \begin{array}{l}\text { relative humidity } \\ \text { revolutions per minute }\end{array} \\ \text { s } & \text { second } \\ \text { SAE } & \begin{array}{l}\text { Society of Automotive Engineers } \\ \text { standard cubic foot/feet per minute }\end{array} \\ \text { scfm } & \text { secant } \\ \text { sec } & \text { stainless steel } \\ \text { SS } & \text { temperature } \\ \text { temp } & \text { ton } \\ \text { ton } & \text { volume percent } \\ \text { vol \% } & \text { versus } \\ \text { vs } & \text { watt } \\ \text { W } & \text { week } \\ \text { week } & \text { weight percent } \\ \text { wt \% } & \text { year } \\ \text { year } & \end{array}$




\begin{tabular}{|c|c|}
\hline $\begin{array}{l}\% \\
\text { psi } \\
\text { psia }\end{array}$ & $\begin{array}{l}\text { percent } \\
\text { pounds per square inch } \\
\text { pounds per square inch, absolute }\end{array}$ \\
\hline $\begin{array}{l}\text { R\&D } \\
\text { RF } \\
\text { RH } \\
\text { rpm }\end{array}$ & $\begin{array}{l}\text { research and development } \\
\text { refrigerator-freezer } \\
\text { relative humidity } \\
\text { revolutions per minute }\end{array}$ \\
\hline $\begin{array}{l}\text { S } \\
\text { SAE } \\
\text { sefm } \\
\text { SS }\end{array}$ & $\begin{array}{l}\text { second } \\
\text { Society of Automotive Engineers } \\
\text { standard cubic foot/feet per minute } \\
\text { secant } \\
\text { stainless steel }\end{array}$ \\
\hline $\begin{array}{l}\text { temp } \\
\text { ton }\end{array}$ & $\begin{array}{l}\text { temperature } \\
\text { ton }\end{array}$ \\
\hline $\begin{array}{l}\text { vol \% } \\
\text { vs }\end{array}$ & $\begin{array}{l}\text { volume percent } \\
\text { versus }\end{array}$ \\
\hline W & $\begin{array}{l}\text { watt } \\
\text { week } \\
\text { weight percent }\end{array}$ \\
\hline & year \\
\hline
\end{tabular}

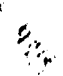

A-3 


\section{APPENDIX B}

\section{STANDARD EDITING MARKS USED AT ORNL}

Proofreader's marks are necessary tools for oditors, authors, typists, and proofreaders. Editors use these marks to indicate suggested changes in a manuscript; authors must understand these marks so that they will know what changes are suggested; typists, word processors, and compositors follow proofreader's marks in incorporating manuscript changes; and proofreaders use them to indicate corrections to be made. Never make up a new proofreader's mark. A complete list is included here for easy reference. A caret $(\wedge)$ should be placed under an inserted punctuation mark to indicate the point of insertion.

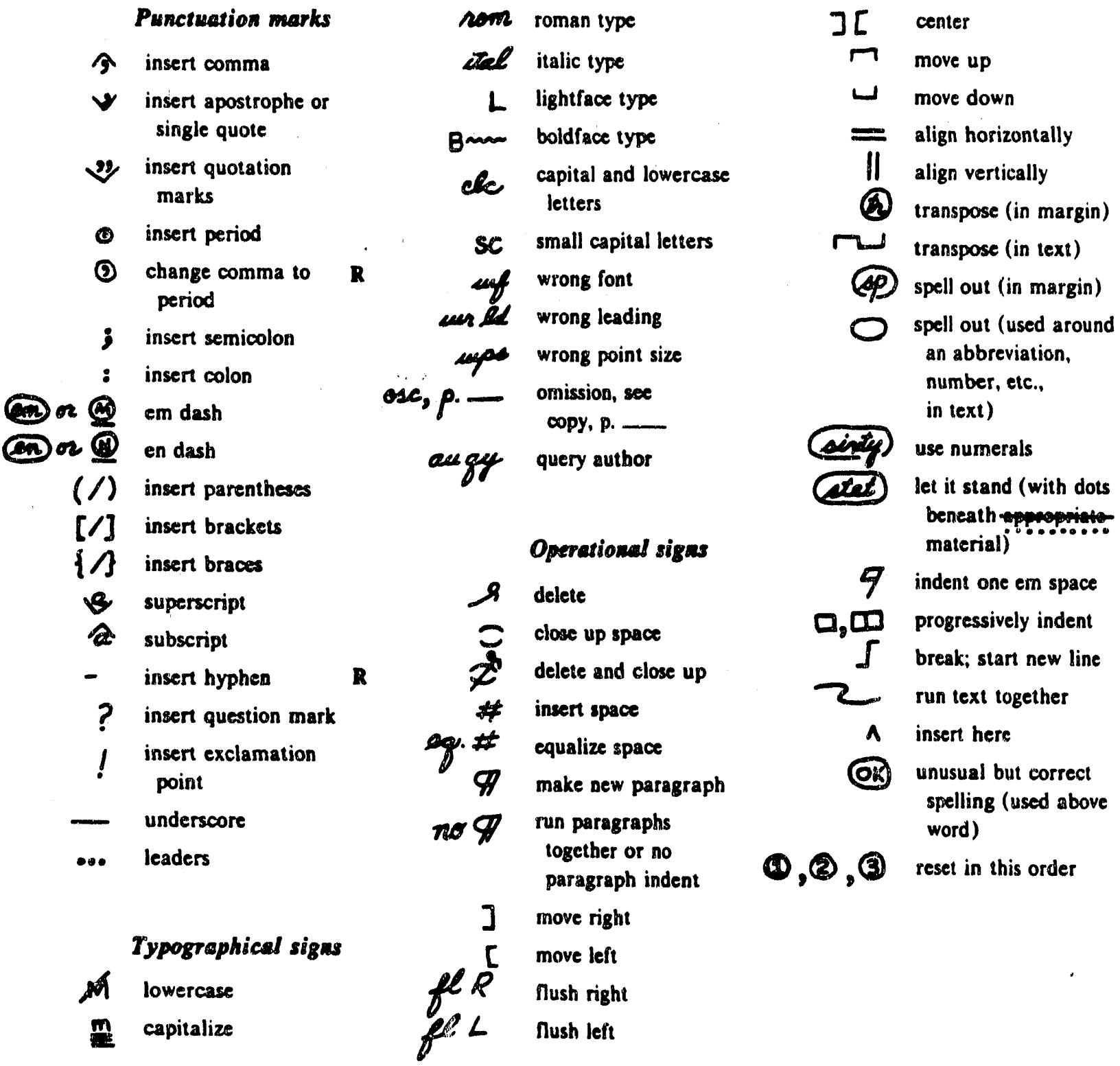

Source: Document Preparation Guide, ORNL/IRO-1, Martin Marietta Energy Systems, Inc., Oak Ridge Natl. Lab., October 1989, p. 6-1.2 
ORNL/TM-12082

\section{INTERNAL DISTRIBUTION}

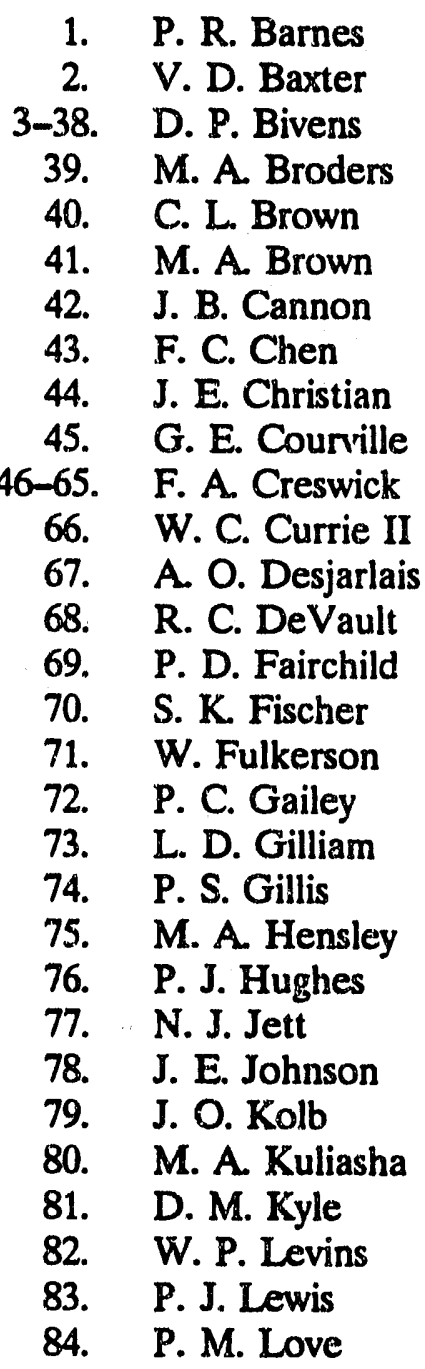

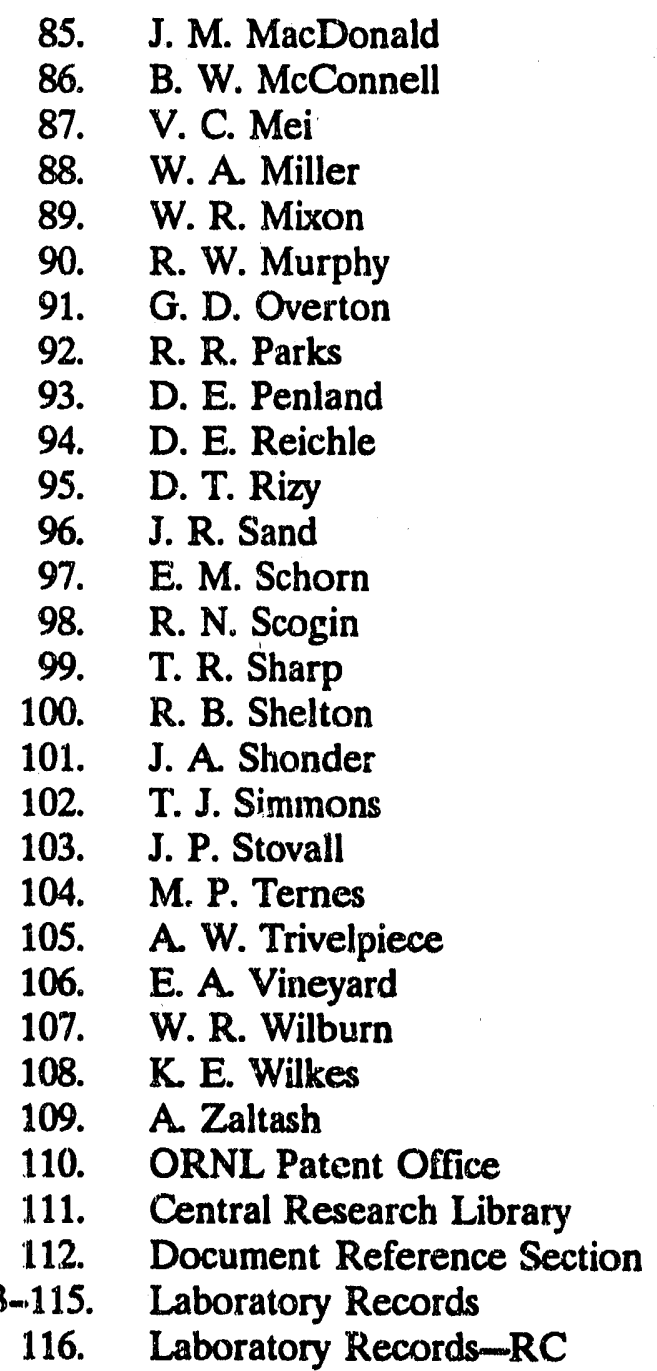

\section{EXTERNAL DISTRIBUTION}

117. D. A. Ball Battelle Columbus Division, 505 King Ave., Columbus, OH 43201-2693

118. W. T. Beale, Sunpower, Inc., 6 Byard St., Athens, OH 45701

119. W. F. Bessler, General Electric CR\&D, Bldg. K1/WS Rm. 108, P.O. Box 8, Schenectady, NY 12301

120. W. J. Biermann, 45 Foxcroft Dr., Fayetteville, NY 13066

121. Dr. B. G. Buchanan, Computer Science Department, University of Pittsburgh, 206 Mineral Industries Building, Pittsburgh, PA. 15260 
122-124. G. Chen, Sunpower, Inc., 6 Byard St., Athens, OH 45701

125. K. Dao, RA Technology, 12 Nace Ave., Piedmont, CA 94611

126. G. Grossman, Faculty of Mechanical Engineering, Technion-Israel Institute of Technology, Haifa, Itrael

127. W. T. Hanna, Battelle Columbus Division, 505 King Ave., Columbus, OH 43201-2693

128. Dr. A. Hirsch, Vice President, Environmental Sciences and Director, Washington Operations, Midwest Research Institute, 5109 Leesburg Pilke, Suite 414, Falls Church, VA 22041

129. Dr. H. M. Ingram, Director, Udall Center for Studies in Public Policy, The University of Arizona, 803/811 East First Street, Tucson, AZ 85719

130. C. D. MacCracken, President, Calmac Manufacturing Corporation, 101 West Sheffield Avenue, P.O. Box 710, Englewood, NJ 07631

131-140. OS11, P.O. Box 62, Oak Ridge, TN 37831

141. H. Perez-Blanco, 314 Mechanical Engineering Bldg., Penn State University, University Park, PA 16802

142. . B. A. Phillips, Phillips Engineering Co., 721 Pleasant St., St. Josephh, MI 49085

143. J. Rasson, R.A Technology, 12 Nace Ave., Piedmont, CA 94611

144. J. B. Shrago, Director, Office of Technology Transfer, Vanderbilt University, 405 Kirkland Hall, Nashville, TN 37240

145. J. Smith, Massachusetts Institute of Technology, Dept. of Mechanical Engineering, Cryogenic Engineering Laboratory, Bldg. 41-204, 77 Massachusetts Ave., Cambridge, MA 02139

146. W. T. Syniuta, Advanced Mechanical Technology, Inc., 141 California St., Newton, MA 02158

147. W. Waldron, Mechanical Technology, Inc., 968 Albany-Shaker Rd., Latham, NY 12110

148. M. A. White, Stirling Technology Co., 2952 George Washington Way, Richland, WA 99352

149. Dr. M. Williams, Professor, Department of Econornics, Northern Illinios University, DeKalb, IL 60115

150. W. J. Zerull, Tectonics Cos., 9556 West Bloomington Fwy., Minneapolis, MN 55431

151. Office of Assistant Manager for Energy Research and Development, DOE-OR, P.O. Box 2001, Oak Ridge, TN 37831-8600 

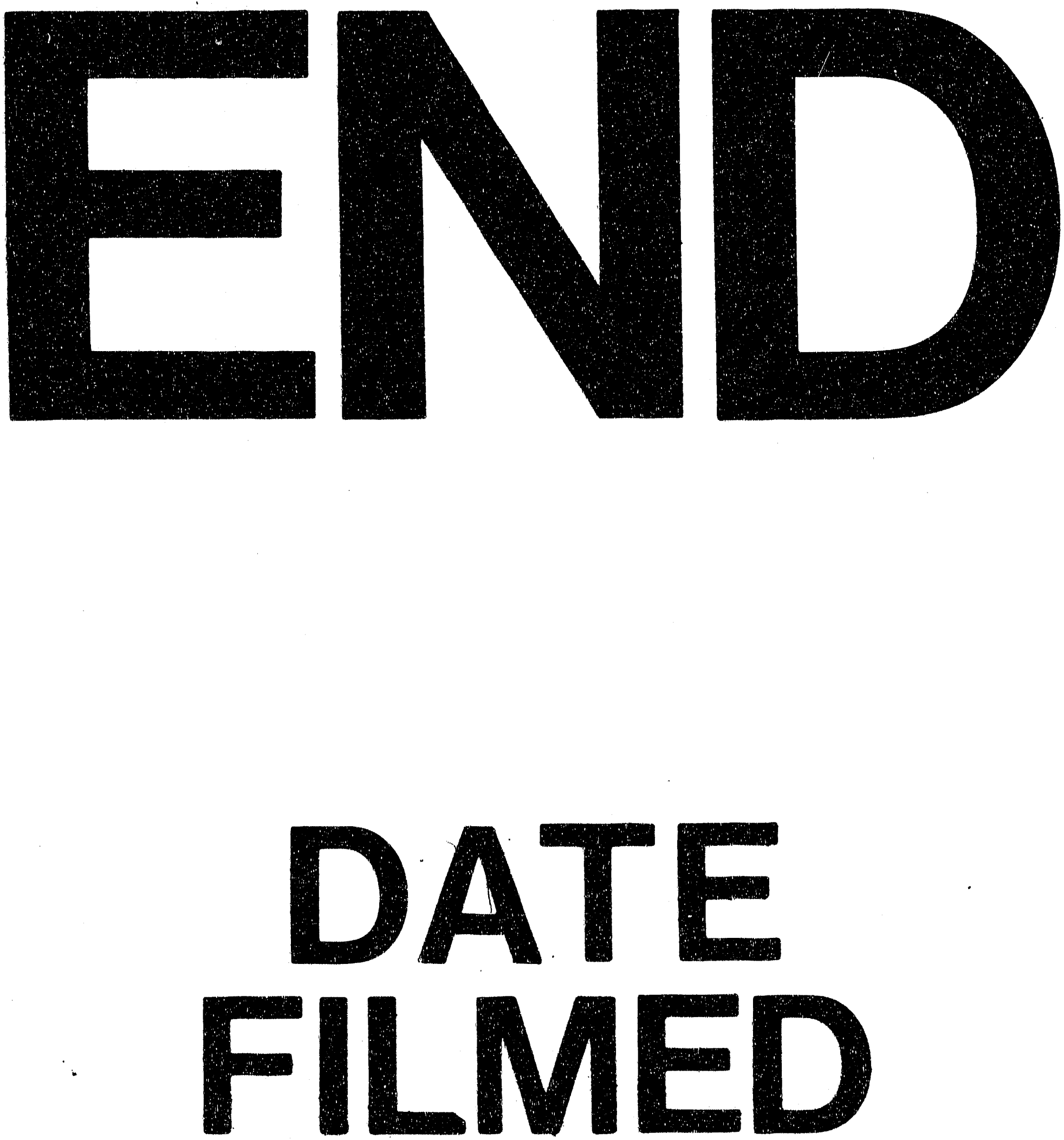

1

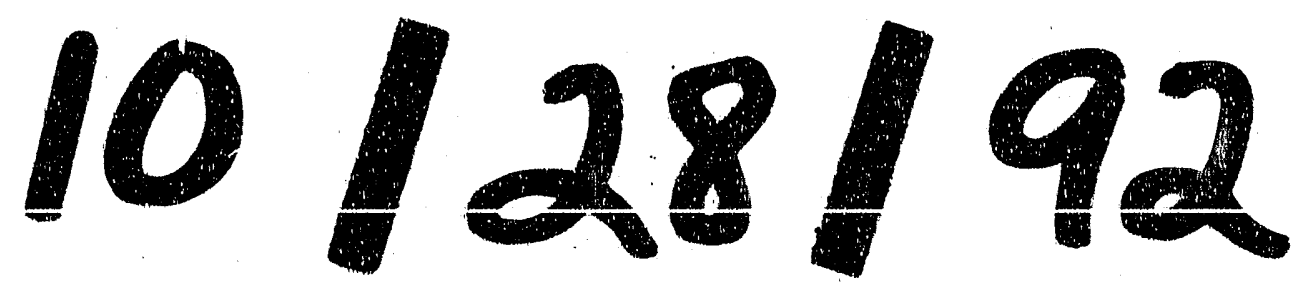


